\title{
Sending money home: Transaction cost and remittances to developing countries
}

\author{
Junaid Ahmed $^{1}$ | Mazhar Mughal ${ }^{2}$ | Inmaculada Martínez-Zarzoso ${ }^{3,4}$
}

${ }^{1}$ Pakistan Institute of Development Economics, Islamabad, Pakistan

${ }^{2}$ Department of Finance, Pau Business School, Pau, France

${ }^{3}$ Department of Economics, Georg-August University of Göttingen, Göttingen, Germany

${ }^{4}$ Department of Economics, University Jaume I, Castellón, Spain

\section{Correspondence}

Junaid Ahmed, Pakistan Institute of Development Economics, Georg-AugustUniversität Göttingen, Göttingen, Germany. Email: junaid.ahmed@wiwi.unigoettingen.de

\begin{abstract}
Reducing the cost of remitting is one of the targets within the 2030 Sustainable Development Goals (SDG 10). A key factor that causes migrants to use informal channels when sending money back home is the high cost of transferring funds through formal channels. This study examines whether and to what extent the reduction in the cost of sending remittances increases the flow of remittances to developing countries, and whether larger amounts are remitted when the cost per transaction decreases (the so-called scale effect). It uses bilateral data on remittance flows and exploits a novel dataset covering transaction costs for 30 sending and 75 receiving countries for the period 2011-2017. A gravity model of remittance flows is estimated using panel data and instrumental variable techniques to address endogeneity issues. We find that transaction cost is a significant predictor of the volume of formal remittances. A $1 \%$ decrease in the cost of remitting USD 200 leads to about a $1.6 \%$ increase in remittances. This association is robust to the different models and techniques employed. The findings suggest that policies designed to increase formal remittances need to focus on decreasing the cost of remitting through formal channels.
\end{abstract}

\section{K E Y W O R D S}

bilateral remittances, cost of remitting, developing countries, international migration 


\section{INTRODUCTION}

Remittances represent one of the largest sources of foreign exchange earnings for low- and middleincome countries (LMICs). For many countries, these flows exceed the flows of foreign direct investment (FDI) and official development aid (ODA). The developing world has witnessed rapid growth in the recorded flows of remittances, which in 2018 amounted to USD 529 billion, up from around USD 342 billion in 2010 (World Bank, 2019a). According to official figures, remittance flows to LMICs have grown by $54 \%$ compared to 2010 . These figures are probably underestimated, since a large proportion of transfers are made through informal channels such as hundi, hawala, etc. The amount of informal remittances could be around $50 \%$ or more of that recorded in the balance of payment statistics (Freund \& Spatafora, 2008).

Given the importance of remittances for developing countries, understanding how to bring down the cost of remitting is of interest for academics and policymakers alike (Beck \& Martínez Pería, 2011; Kakhkharov et al., 2017; Ratha et al., 2018). Transaction cost is not usually an important issue for large financial flows (for instance, those involved in international trade, FDI or development assistance), as charges tend to be a negligible proportion of the total amount transferred. For remittances, however, transaction costs are often high in relative terms. Remittance service providers in the formal sector usually charge fees of $10 \%-15 \%$ of the principal amount to handle the small transfers typically sent by poor migrants (Ratha, 2006). This cost puts a financial burden both on the migrants who remit and on the recipient, who consequently benefits less from their overseas family member's efforts. On the supply side, major international banks tend to focus on high-value remittance services rather than those tailored to migrant workers (Solimano, 2003; Ratha \& Riedberg, 2005). In addition, poor immigrants may feel uneasy about using a bank for remittance services and tend to prefer smaller financial institutions, money transfer operators (MTOs) or informal services, such as the hawala system, relatives, friends, transport companies, etc.

Bringing down the cost of remitting is beneficial for a number of reasons: it increases the funds available to migrants and members of their households who stay behind and could contribute to the development of the migrant's country of origin ${ }^{1}$ it helps increase flows through formal channels, especially banks, thereby contributing to the receiving country's foreign account balance; and it helps improve financial access for the poor, thereby expanding the formal financial sector (Beck \& Martínez Pería, 2011; Freund \& Spatafora, 2008). Reducing costs does not necessarily mean squeezing the profits of the remittance service providers; indeed, the cost of providing those services often depends on external factors (market structure, level of competition, migrant stock). Lower prices, moreover, would lead to more frequent transactions by remitters, thereby offering increased volume to the service providers (Freund \& Spatafora, 2008; Ratha, 2006).

In recent years, there has been increasing interest among multilateral institutions - such as the World Bank, IMF, UN-in formalising remittances. An important factor that causes migrants to use informal channels is the high cost of transferring funds through formal channels (Gibson et al., 2006; Yang, 2011). The average cost of transferring USD 200 to developing countries remained at $7 \%$ in the first quarter of 2019, about the same level as in previous quarters (World Bank, 2019). This is more than double the Sustainable Development Goal (SDG) target of 3\% to be achieved by the year 2030. The cost of remittance services can vary substantially, by region and transfer methods. For instance, the cost is the lowest in South Asia, while sub-Saharan Africa continues to have the highest average cost (World Bank, 2019b). Banks are the most expensive routes for sending remittances, with an

\footnotetext{
${ }^{1}$ It is important to mention that there is a body of research indicating that remittances may not contribute to the economic development of recipient economies (see, for example, Barajas et al. 2009; Siddique et al. 2012).
} 
average cost of $10.9 \%$ in Q1 2019, while post offices are cheaper with a cost of $7.6 \%$ in the same period. Reducing the cost of remitting is an important policy objective, which can help to increase the contribution of remittances to the formal economy, enhance financial inclusion and increase the net income of receiving households. Literature on the cost of remitting and remittance inflows is not conclusive. A number of studies incorporate geographical distance as a proxy for the cost of remitting in order to overcome the paucity of data on remittance cost. Greater distance between countries is associated with increased costs of sending money, thus negatively affecting remittance inflows (Frankel, 2011; Lueth \& Ruiz-Arranz, 2008; McCracken et al., 2017). However, De Sousa and Duval (2010) report the opposite result: they find a significant positive relationship between geographical distance and remittances. The authors argue that this result can be explained by the loan repayment hypothe$\operatorname{sis}^{2}$. One issue with the above literature is that using geographical distance, a variable that is timeinvariant in nature, to proxy transaction cost does not allow the researcher to consider technological changes and financial innovations that have made remitting more convenient. Likewise, it does not account for migration concentration: corridors with a greater network of migrants and higher competition for remittance services exhibit consistently lower costs than others (Beck \& Martínez Pería, 2011) indicating a lower level of information friction that further reduces the transaction cost of sending remittances.

Taking a different perspective, Ahmed and Martínez-Zarzoso (2016) and Kakhkharov et al. (2017) focus on the cost of remitting for specific recipients, with data on remittances spanning the period from 2003 to 2013/2014. As expected, they find that transaction cost negatively affects the volume of remittances. Whereas the former study focuses exclusively on remittances sent to Pakistan, the latter considers remittances received in 12 post-Soviet economies. The results lack external validity given their national and regional focus. In terms of methodology, a one-side gravity model—with only one recipient country - is estimated in Ahmed and Martínez-Zarzoso, (2016) meaning it is not possible to properly account for multilateral resistance factors, while Kakhkharov et al. (2017) estimate basic panel data models at the country level with fewer than 100 observations. To address the limitations that these studies have in terms of methodology, scope and data used, this study uses bilateral data on remittance flows and exploits a global dataset of transaction costs for 30 sending nations and 75 receiving countries for the period 2011-2017. Employing an instrumental variable (IV) design, this paper examines the question of whether and to what extent the cost of remittances reduces the flow of formal remittances to developing countries ${ }^{3}$.

The contribution of this paper is twofold. First, this paper is the first to estimate the effect of transaction cost on remittances using a global sample of countries, thereby departing from previous studies that were more limited in scope (Ahmed \& Martínez-Zarzoso, 2016; Mookerjee \& Roberts, 2011; among others) or only had a direct measure of transaction costs for a single year (Freund \& Spatafora, 2008). Second, we employ a number of external instruments à la Altonji and Card (1991) and Card (2001) to tackle potential endogeneity between the volume of remittances and transfer fees. We instrument the cost of remitting with initial origin-specific migrant concentration interacted with indicators of financial access and the speed of transferring funds.

\footnotetext{
${ }^{2}$ This hypothesis states that if the cost of migration were borne by the family, remittances could be considered as a loan repayment.

${ }^{3}$ As pointed out by an anonymous referee, it is virtually impossible to know whether transaction costs reduce total remittances, given that it is difficult to estimate informal remittances (even formal remittances are hard to estimate with precision). It could also be the case that remittance senders have a target amount they would like or need to remit and hence only the flow of remittances through formal rather than informal channels is affected by the cost.
} 
The rest of the paper is structured as follows. The next section provides an overview of the existent literature on transaction cost and remittance inflows, including the role and interpretation of the geographical distance variable in these models. Section 3 outlines the gravity model of remittances and discusses data sources. Section 4 presents the estimation results and Section 5 outlines the results of a number of robustness tests. Finally, Section 6 summarises the results and presents some policy-related conclusions.

\section{I LITERATURE REVIEW}

The existing literature on the decision to remit is largely comprised of microeconometric studies. The distinctions between the migrant's motives for the remittance decision, such as personal (altruism, self-interest or strategic motives) and familial arrangements (insurance and loan repayment), have been studied in great detail (Azizi, 2019; Carling, 2008; Rapoport \& Docquier, 2006; Ruiz \& VargasSilva, 2009; Schiopu \& Siegfried, 2006). These different motives provide a rigorous justification for the macroeconomic model estimated subsequently. A migrant with altruistic motives sends money to financially support his/her family back home (Anwar \& Mughal, 2012; Johnson \& Whitelaw, 1974; Lucas \& Stark, 1985). Migrant remittances can also be considered the result of an implicit contract between the members of the migrant household. For instance, a migrant may remit money to pay back the implicit loan taken to cover the cost of the migration process and the spending on education and training incurred by his/her household (Ilahi \& Jafarey, 1999; Johnson \& Whitelaw, 1974; Lucas \& Stark, 1985; Stark \& Lucas, 1988). The money sent by the migrant can also be due to exchange motives. If the migrant's stay-behind family members take care of the migrant's children, physical assets and other financial and social interests, he/she may remit money to pay for these services rendered (Cox, 1987; Cox et al., 1998). Finally, a migrant aspiring to a share of the family inheritance may send money back home in order to maintain good relations with his/her parents and the family members.

At the macroeconomic level, various studies have attempted to gauge the role of these motives for remittances by examining factors that determine remittance inflows. A review of 17 empirical studies finds that the economic conditions in the source and recipient country and the migrant stock seem to be the dominant factors behind increased remittances (Hagen-Zanker \& Siegel, 2007). This suggests that remittances would be larger for countries with a larger diaspora and when the diaspora is located in wealthier countries (Singh et al., 2011). Similarly, when deciding to remit, migrants respond more to the economic conditions of the host country relative to those of the home country (Vargas-Silva and Huang, 2006; Coulibaly, 2009). In another study, skilled migrants with greater capacity for higher earnings are found to be more likely to remit more, mitigating the negative impact of the brain drain effect in the origin country (Beine et al., 2008). However, countries that send a larger share of highskilled migrants receive less in per capita remittances than countries that send a larger proportion of low-skilled migrants (Adams, 2009). Other important factors that encourage remittances are improved financial infrastructure (Ajide \& Raheem, 2016; Ezeoha, 2013; Mallick, 2017; Mookerjee \& Roberts, 2011), quality of institutions (Ajide \& Raheem, 2016; Lartey \& Mengova, 2016) and lower exchange rate uncertainty (Higgins et al., 2004; Hysenbegasi \& Pozo, 2008). Meanwhile, for factors such as GDP per capita, dependency ratio, interest rate, inflation and exchange rate (Azizi, 2019; Ezeoha, 2013; Mallick, 2017; Ruiz \& Vargas-Silva, 2009), the impact is generally found to be inconclusive.

In the past two decades, research on financial inflows has gathered momentum, covering a wide range of issues such as the formalisation of transfers, the reduction of the transfer costs of remittances, the relationship between remittances and financial sector development, the use of remittances for investment, the externalisation of remittance expenditure and the economic impact of remittances. 
Remittances are now increasingly seen as a 'new development mantra' (Kapur, 2004). In an early study on the topic, Lueth and Ruiz-Arranz (2008) examine bilateral remittances for 11 countries in Asia and Europe for the period 1980-2004 in order to determine the factors that drive those flows. Their results indicate that economic activity in the sending and recipient country and other gravity variables account for more than $50 \%$ of the variation in remittances. The study finds that underdeveloped financial sectors in the home country may discourage remittances through formal channels. Distance, used as a proxy for financial transaction cost, is reported to have a negative effect on remittance flows. Similarly, Frankel (2011), using the same dataset, finds that distance is negatively associated with remittances. McCracken et al. (2017) used bilateral remittances to 27 Latin American and Caribbean countries originating from 18 industrialised countries in a gravity setting. They find that greater geographical distance is associated with a lower volume of remittances. This negative correlation supports the information friction channel explanation, as greater distance increases the cost of monitoring how remittances are spent by raising the cost of trips back home or by reducing the frequency of phone calls due to differences in time zones.

Other studies fail to find the above-mentioned significant negative association between the volume and cost of remittances. De Sousa and Duval (2010), in a case study on Romania, observe that both recipient and sending countries' economic size and geographical distance appear to impact bilateral flows positively. The relationship found between remittances and distance gives some support to the loan repayment hypothesis. In another study, using data on remittances from 21 Western European to 7 neighbouring EU countries, Schiopu and Siegfried (2006) do not find evidence indicating that the cost of remittances, proxied by the number of Western Union agents per capita, explains remittance flows. However, the effect is positive for the pair of countries that do not share a common border, indicating that for those non-neighbouring countries more remittances are sent when the availability of financial services increases.

Departing from previous literature, Ahmed and Martínez-Zarzoso (2016) use the transaction cost of remitting to study its impact on remittance flows. Using bilateral data on remittance flows to Pakistan from 23 sending countries, the study finds a significant and negative effect of transaction cost on the remittance inflows, suggesting that higher transaction costs result in either a greater use of informal channels for money transfer or the remitters refraining from sending money to their homes. The authors suggest that the reduction in transaction costs should both increase the remittance volume and enhance financial inclusion by redirecting the remittance flows from informal to formal channels. In a similar vein, Kakhkharov et al. (2017) investigate remittance flows to former Soviet Union countries by applying panel data techniques. They find that a reduction in transaction costs and depreciation of the currency in the sending country are the main factors that influence the growth of recorded remittances. The negative relationship found between transaction costs and recorded remittances suggests that migrants switch from informal channels to formal ones in order to send remittances when costs are low. In an earlier study, Freund and Spatafora (2008) explore the determinants of remittances and their associated transaction costs - available for the year 2005 for a cross section of 102 developing countries-finding that recorded remittances depend positively on migrant stock and negatively on transaction $\operatorname{cost}^{4}$. When examining the determinants of the latter, they find that transfer costs are lower when financial systems are more developed and exchange rates are less volatile.

\footnotetext{
${ }^{4}$ The effect is economically relevant, indicating that a one-percentage point increase in the fees is associated with a reduction in remittances of around $15 \%$. However, these results are based on data for a single year and subject to endogeneity issues. When using instrumental variables, the magnitude of the effect increases to $20 \%$, but the coefficient is only significant at the $10 \%$ level.
} 
From this overview of the literature, we can see that the empirical evidence on the significance and direction of association between the volume of remittances and their cost is mixed, with results depending on the quantity and quality of data and the methodology employed. Until recently, an additional difficulty has been the lack of available cross-country longitudinal data on the cost of remitting.

\section{3 | MODEL, DATA AND EMPIRICAL STRATEGY}

\section{1 | Model specification}

The gravity model of trade has been widely used to analyse the effect of trade liberalisation policies and reductions of trade costs on bilateral trade flows. It has also been broadly applied to the analysis of other international flows such as FDI (Bénassy-Quéré et al., 2007; Demekas et al., 2005), international migration (Lewer \& van den Berg, 2008; Mayda, 2010) and equity holding and cross-border banking (Portes \& Rey, 2005; and Brei \& Von Peter, 2018). Its application to the analysis of international remittances has been less common, but analogous to the concept of gravity in trade, bilateral remittance flows can also be mainly explained by the economic mass of the countries involved in the transaction, and relative frictions that limit the volume of transactions captured by transaction cost.

In this study, we employ an augmented gravity model in which bilateral remittance flows are explained by the GDPs of both the remittance-sending $(i)$ and the recipient countries $(j)$ and by the transaction cost $\left(\right.$ Transcost $\left._{i j t}\right)$. The baseline empirical model builds on the literature that uses countrylevel data and cross-country regressions to explore the drivers of bilateral remittances using the gravity model. We build on the approach proposed by Lueth and Ruiz-Arranz (2008) and Ahmed and Martínez-Zarzoso (2016) by taking natural logs of the original multiplicative gravity model.

The linearised gravity model of remittance flows from the sending $(i)$ to recipient countries $(j)$ in the year $(t)$ is specified as follows:

$$
\begin{gathered}
\ln \left(\text { Remit }_{i j t}\right)=\beta_{0}+\beta_{1} \ln \left(\text { GDP }_{i t}\right)+\beta_{2} \ln \left(\text { Transcost }_{i j t}\right)+\beta_{4}\left(\text { Lang }_{i j}\right) \\
+\beta_{5}\left(\text { Border }_{i j}\right)+\beta_{6}\left(\text { Colony }_{i j}\right)+\beta_{7} \ln \left(\text { Stockmig }_{i j t}\right) \\
+\beta_{8} \ln \left(\text { Exchrstab }_{i t}\right)+\beta_{9} \ln \left(\text { Exchrstab }_{j t}\right)+\tau_{t}+\mu_{i j}+\varepsilon_{i j t}
\end{gathered}
$$

where Remit $t_{i j t}$ indicates bilateral remittances (in natural logarithms) between the sending country $i$ and the recipient country $j$ at time $t$ comprising funds classified as workers' remittances, employee compensation, and migrant transfers. The explanatory variables $G D P_{i t}$ and $G D P_{j t}$ stand for the gross domestic product of the sending country $(i)$ and the recipient country $(j)$ in period $t$. Transcost $t_{i j t}$ indicates the transaction cost of sending money from country $i$ to country $j$. We take the cost of sending USD 200 as a percentage of the amount remitted as the main cost indicator. The cost of sending USD 500 is used for a robustness check. Stockmig ${ }_{i j t}$ denotes the stock of migrants from $j$ that live in country $i$ at time $t$. We include as explanatory variables the exchange rate stability (Exchrstab) in the sending and receiving countries as a proxy for financial risk, since Amuedo-Dorantes and Pozo (2004), El-Sakka and McNabb (1999), Freund and Spatafora (2008) and Faini (1994) find that exchange rate is a significant driver of remittance flows. $\mu_{i j}$ denotes bilateral unobserved heterogeneity, which is alternately treated as fixed or random. In the former case, the time-invariant variables are dropped from the model due to the within transformation.

In addition to these factors, in some estimations we also include indicators of physical and cultural distance, which could represent the cost of acquiring information. Unlike goods, financial assets are 'weightless' and hence distance is not a good proxy for transaction costs. Distance could however serve as a proxy for information frictions (Portes \& Rey, 2005). Countries that are geographically 
close tend to know more about each other. Common language, common border (contiguity) and colonial history are used to measure the cultural similarities between the countries $i$ and $j$. Given that these factors are time-invariant, in some estimations we use a correlated random-effects (CRE) model that adds the means of the time-variant variables to the model and enables us to estimate the coefficients of the time-invariant variables.

We extend the baseline model by adding other sending and recipient country characteristics that are likely to influence the cross-border remittance flows. The extended model is given by:

$$
\begin{aligned}
\ln \left(\text { Remit }_{i j t}\right) & =\beta_{0}+\beta_{1} \ln \left(G D P_{i t}\right)+\beta_{2} \ln \left(G D P_{j t}\right)+\beta_{3} \ln \left(\text { Transcost }_{i j t}\right) \\
& +\sum_{k=1}^{K} \gamma_{k} X_{i k t}+\sum_{k=1}^{K} \delta_{k} X_{j k t}+\mu_{i j}+\tau_{t}+\varepsilon_{i j t}
\end{aligned}
$$

In equation (2), the vector of control variables is represented by $X$, which includes, among other variables, exchange rate variables, liquid liabilities to GDP for both sending and recipient countries as a measure of financial development, and government stability proxied by institutional quality. All the variables except for dummies are in natural logs and their estimated coefficients can therefore be interpreted as elasticities. Model (2) is estimated using a generalised method of moments (GMM) estimator with fixed effects to account for the potential endogeneity of the target variable. The identification strategy is outlined in detail in subsection 3.3.

\section{2 | Data and variables}

The summary statistics of the main variables used in the empirical analysis are shown in Table 1. Table A1 shows the description of the variables used in the estimations, units of measurement and sources of the data used. The list of sending and receiving countries included in the dataset is shown in Table A2 in the Appendix.

Bilateral remittances received by country $i$ from country $j$ in current US dollars are estimated by the World Bank using the method described in Ratha and Shaw (2007). Annual remittance matrices are combined to generate the bilateral remittances panel for the period 2011-2017. The bilateral migration data used in this study come from two distinct sources. The starting point is the bilateral migration stocks for destination countries by major countries of origin retrieved from the United Nations Population Division. The calculations are based on the 2015 and 2017 bilateral migration matrices. The second step involves a collection of similar immigration data from the OECD Database on Migration to obtain data on stocks of emigrants from various developing countries living in OECD countries. These two datasets are merged to generate an indicator of migrant stocks for both OECD and non-OECD countries for the period 2011-2017.

Data for remittance costs are taken from Remittance Prices Worldwide (RPW), a database managed by the World Bank. The transaction cost data are available on a quarterly basis for different channels such as banks, MTOs, post offices and mobile phones. We constructed an indicator for the average transaction cost of sending USD 200 and USD 500. The total cost charged by a provider includes the remittance transaction fee and the implicit exchange rate cost that applies when the remittance transactions are paid in local currencies (computed in this database when the foreign exchange rate applied by the remittance service provider is known $)^{5}$.

\footnotetext{
${ }^{5}$ The implicit exchange rate cost is the difference between the exchange rate used by the provider and the central exchange rate as reported by Bloomberg (also called exchange rate spread).
} 
TA B LE 1 Descriptive summary statistics

\begin{tabular}{|c|c|c|c|c|c|}
\hline Variable & Obs. & Mean & SD & Min & Max \\
\hline $\ln$ (Remit) & 1643 & 5.74 & 1.78 & -5.74 & 10.31 \\
\hline $\ln$ (Remit per migrant) & 1153 & 7.84 & 1.11 & 1.52 & 11.15 \\
\hline $\ln ($ Remit per capita) & 1643 & 2.04 & 2.03 & -9.72 & 7.46 \\
\hline $\ln ($ Trans. cost 200) & 1365 & 2.00 & 0.48 & 0.24 & 3.18 \\
\hline $\ln ($ Trans. cost 500) & 1363 & 1.52 & 0.48 & -0.22 & 2.92 \\
\hline $\ln$ (Distance) & 1673 & 8.35 & 0.77 & 5.75 & 9.83 \\
\hline $\ln$ (Stock of migrants) & 1160 & -2.12 & 1.39 & -7.47 & 2.54 \\
\hline $\ln \left(\mathrm{GDP} \_P P P\right)_{\mathrm{i}}$ & 1701 & 14.35 & 1.27 & 10.85 & 16.79 \\
\hline $\ln \left(\mathrm{GDP} \_\mathrm{PPP}\right)_{\mathrm{j}}$ & 1694 & 12.54 & 2.18 & 6.28 & 16.96 \\
\hline Exc. rate $s t a b_{i}$ & 1701 & 0.94 & 0.10 & 0.38 & 1.00 \\
\hline Exc. rate $s t a b_{j}$ & 1526 & 0.92 & 0.14 & 0.08 & 1.00 \\
\hline $\ln$ (Bilateral exchange rate) & 1636 & 3.40 & 2.64 & -5.33 & 10.26 \\
\hline $\ln \left(\right.$ liquid liabilities to $G D P_{i}$ ) & 1336 & 4.49 & 0.37 & 3.56 & 5.38 \\
\hline $\ln \left(\right.$ liquid liabilities to $G D P_{j}$ ) & 1417 & 3.98 & 0.62 & 2.33 & 5.49 \\
\hline Border & 1673 & 0.05 & 0.23 & 0.00 & 1.00 \\
\hline Language & 1673 & 0.39 & 0.49 & 0.00 & 1.00 \\
\hline Colony & 1673 & 0.15 & 0.35 & 0.00 & 1.00 \\
\hline Instit $_{\mathrm{i}}$ & 1701 & 0.59 & 0.24 & 0.00 & 1.00 \\
\hline Instit $_{j}$ & 1526 & 0.58 & 0.15 & 0.00 & 1.00 \\
\hline
\end{tabular}

Note: Definitions and data sources of the variables are given in Table A1.

Figure 1 shows that, starting in 2015, remittance costs have decreased steadily, potentially due to the entry of new players in the market, new technologies supporting digital payments and the progress made in improving financial inclusion. The cost of sending remittances varies substantially. For instance, South Asia had the lowest cost of around 5.2\% in 2017, which represents a drop of about 24 percentage points from the level of $6.8 \%$ estimated for the year 2011. Similarly, the cost of remitting declined in all regions from 2016 to 2017, with the notable exception of sub-Saharan Africa (SSA). SSA remains the most expensive corridor for remittances, with an average cost stubbornly hovering around $12 \%$ in 2011-2012 and 9.4\% in 2017. Despite the declining trends seen in recent years, the average cost of sending USD 200 still exceeds the SDG goal of 3\%; for example, the cost of sending to East Asia and Pacific (EAP) is around 8.5\%, 7.5\% to the Middle East and North Africa (MENA), 7.2\% to Europe and Central Asia and 6.2\% to Latin America and the Caribbean (Figure 1).

The scatter plots in Figures A1 and A2 in the Appendix show the relationship between remittance flows and the cost of sending USD 200, in natural logs, for the years 2011 and 2017, respectively. The figures suggest that lower costs of remitting are associated with higher amounts of formal remittances. Similarly, the large cluster of observations around high remittance shares seems to be associated with low costs of remitting; to some extent, this could indicate the existence of a scale effect, given that remittance costs are lower in high-volume corridors.

Table A3 shows the correlation matrix for the variables included in the study. We observe that remittances are positively correlated with most of the variables, but negatively correlated with liquid liabilities in the sending country and transaction cost. The highest correlation for remittances is with the stock of migrants (0.76). Strong correlations are also found with other economic and financial 


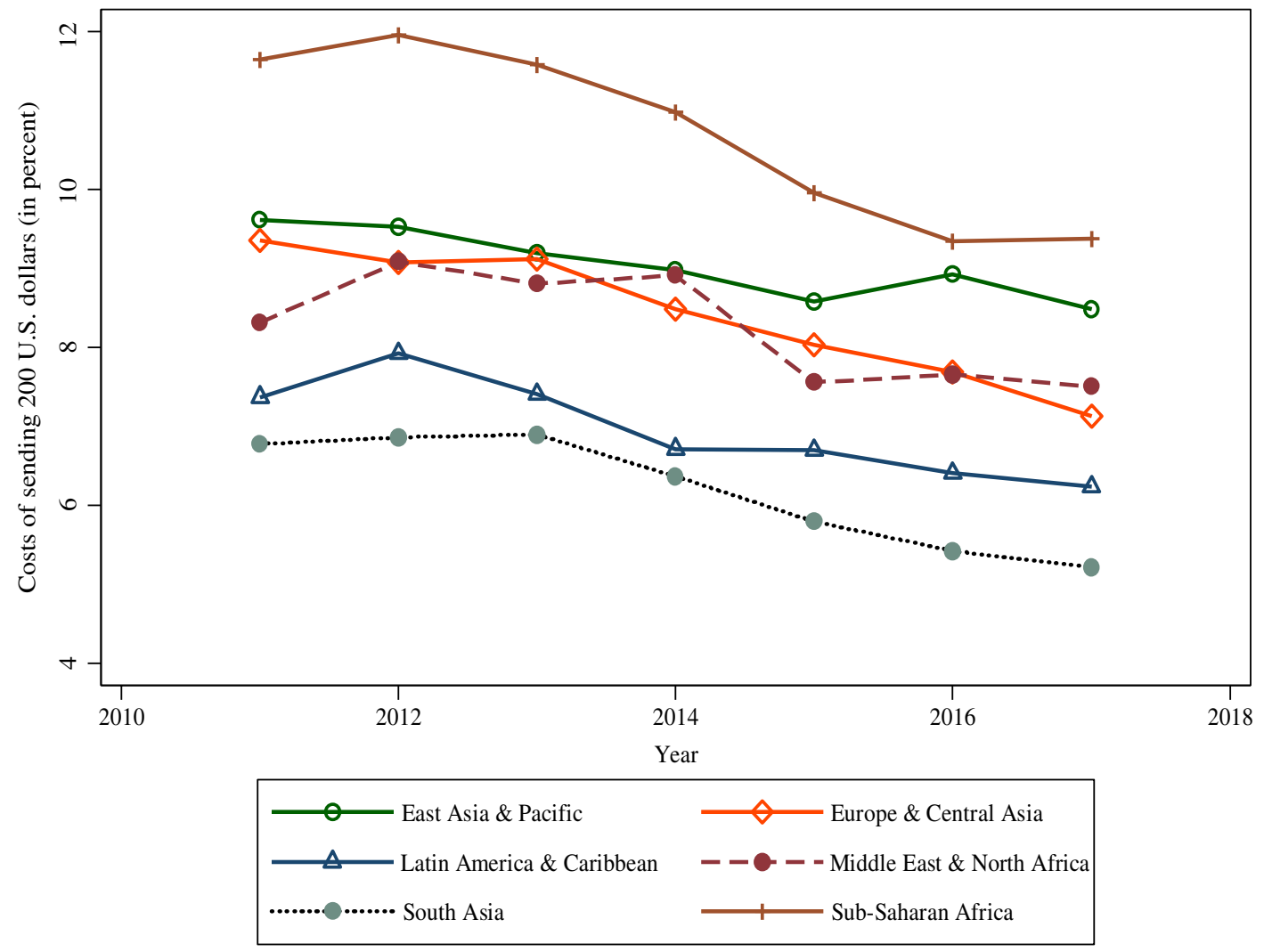

F I G U RE 1 Regional overview of the costs of sending USD 200 (2011 and 2017).

Source: Remittance Prices Worldwide Database 2019, World Bank.

indicators (cost, sending and receiving country GDP, exchange rate stability and liquid liabilities), whereas they are weak for institutional and cultural indicators. An interesting observation is that cost is strongly correlated only with remittances and migrant stock and not with financial development or national output.

\section{3 | Empirical strategy}

A variety of empirical techniques are employed in the study. The model is first estimated using the standard fixed effects model (FEM) based on the Hausman test result, which indicates that the country fixed effects are correlated with the regressors $(p$-value $=0.003)$. A random-effects estimator $(\mathrm{REM})$ would therefore yield biased results. The FEM is a consistent approach to deal with unobservable country pair effects. However, it does not provide a direct estimation of the coefficients of timeinvariant variables as it uses a within transformation to eliminate the time-invariant unobservable country effects, which also wipes out all explanatory variables that are time-invariant, such as geographical distance and common language. In this case, no statistical inference can be made for these variables if they are included in the original model based on the theory. This is in contrast to REM, which rests upon the strong assumption of exogeneity of all explanatory variables with respect to the error term. The solution we adopt is to use the CRE method proposed by Mundlak (1978), which uses 
a linear projection of the time-invariant unobserved heterogeneity to relax the strong exogeneity assumption. The CRE method is easily implemented in practice by augmenting the REM with the mean of the explanatory variables that change over time (Wooldridge, 2010). It can be shown that the coefficients of the time-varying explanatory variables are identical to the FEM estimates (Wooldridge, 2010).

Nevertheless, it is still possible that transaction costs are endogenous to remittances; failing to account for this in the model might result in biased estimates. Remittances may cause shifts in transaction costs; in other words, market size or economies of scale might also have important effects (Beck \& Martínez Pería, 2011; Freund \& Spatafora, 2008). Higher remittance flows reduce transaction fees through greater competition in larger markets or returns to scale. In this case, there would be an identification problem due to reverse causality. It is also possible that economic or socio-political variables omitted from our model may affect both the volume and cost of remitting. The most common method to deal with the endogeneity problem is to implement an IV strategy. Consequently, we continue our analysis using a two-step GMM estimator with fixed effects in order to overcome the potential endogeneity $^{6}$. We also perform the Durbin-Wu-Hausman test for endogeneity. A small $p$-value (0.029) indicates that the explanatory variable is correlated with the error term, implying that endogeneity is present. In such a case, estimates using ordinary least square (OLS) would be inconsistent and an IV approach is recommended (Baum et al., 2003, 2007). When applying the IV strategy, the main challenge is to find suitable instruments for the variables that are endogenous to the model.

External instruments should be correlated with the endogenous explanatory variable but should not directly affect the dependent variable. An early example of the use of an IV approach in the migration literature can be found in Altonji and Card (1991) and Card (2001), who instrument current migration with settlement patterns of previous migrants when examining the labour effects of immigration. The underlying assumption is that pull factors which attracted immigrants in the past are uncorrelated with current local demand shocks. In line with this literature, we construct a number of instruments for remittance cost. These include the share of country i's migrant stock in country $j$ 's population interacted with indicators of financial access, namely, bank branches per 100,000 adults and ATMs per 100,000 adults in the sending country, as well as speed of the transfers. The reason for choosing these instruments lies in the fact that origin-specific immigrant networks are considered an important determinant of remittance transfer fees (Beck \& Martínez Pería, 2011; Freund \& Spatafora, 2008). A higher concentration of migrants from a certain country means that there tend to be more remittance services for the remittance corridor in question and greater competition among service providers, leading to lower costs. The indicators of financial access in the sending country also represent the ease with which migrants can use formal remittance services which, in turn, affects the transfer fees charged by the service providers. Following Altonji and Card (1991) and Card (2001), our instruments are defined as:

$$
\text { Inst }_{i t}=\sum_{i} \overline{\operatorname{mig}}_{i g 2011} * f a_{i t}
$$

where $\overline{\mathrm{mig}}_{i g 2011}$ denotes the immigrants from country $j$ residing in country $i$ as a share of the total population of country $i$ in the initial year of the sample period (2011) interacted with financial access indicators (bank branches per 100,000 adults and ATMs per 100,000 adults) in country $i$. As an additional external instrument, we use the speed of delivery of the transfers. This is an important factor that migrants consider when selecting the remittance channel. The longer it takes to process a transaction, the more likely migrants are to use alternative channels to remit money (Ferriani \& Oddo, 2019). Remittance channels differ

${ }^{6}$ The STATA xtivreg2 implements with the robust bw(2) gmm2 small options. 
widely in terms of accessibility and speed, with the latter often positively associated with transfer charges. The speed of the transfer, defined as the time needed for the remittance to be available for the receiver, is standardised in six broad categories: $<1 \mathrm{~h}$, same day, next day, 2 days, 3-5 days and 6 days or more, with the categories ranked from 1 to 6 , respectively.

The outcome of the Hansen test for over-identification indicates that the null hypothesis that all our instruments are valid cannot be rejected. We use robust standard errors clustered at the corridor level throughout the analysis in order to control for arbitrary groupwise heteroscedasticity and serial correlation.

\section{4 | MAIN RESULTS AND DISCUSSION}

Table 2 shows models with pair FE in columns (1), (3) and (5) and with correlated RE in columns (2), (4) and (6). These last three models include distance, common language, colonial past and common border variables. The results indicate that none of these variables are statistically significant. In contrast, the association between the cost of remitting USD 200 and the amounts remitted is always statistically significant and with the expected negative sign. The coefficient for the cost variable indicates that a $1 \%$ decrease in the cost of remitting increases the amount of remittances sent by about $0.24 \%$. Finally, in columns (5) and (6) of Table 2 we used for comparison the bilateral exchange rate variable instead of the exchange rate stability variables used in the main model. This variable is found to have a positive association with remittances, indicating that migrants remit more in foreign currency as the domestic currency depreciates. This finding is in line with Singh et al. (2011), who report that depreciation of the recipient country's currency increases remittance flows, as it translates into more local currency per unit of foreign currency. Likewise, the World Bank (2012) argue that an unexpected depreciation of the home country currency can lead to a major surge in remittances as migrants remit their savings to purchase land, houses and other durable assets back home.

In Table 3, we present the results ${ }^{7}$ obtained by using a GMM estimator that accounts for the potential endogeneity of the target variable, transaction cost, gradually adding the control variables indicated in Section 3. The estimated model corresponds to specification (2) in the same section. Time FE are included in all columns to model specific unobservable time effects, and country fixed effects are added to account for unobserved heterogeneity that is time-invariant. The coefficient of remittance cost for remitting USD 200 is negative and statistically significant, and its magnitude increases dramatically in comparison to the results obtained when the model is estimated as specified in equation (1), that is, with FE and CRE (Table 2).

When endogeneity is taken into account, a $1 \%$ decrease in the cost of remitting increases remittances by about $1.57 \%$, that is, more than proportionally. The elasticity of transaction cost is over six times that shown in columns (3) and (4) of Table 2, indicating a substantial underestimation in the baseline results. This result is obtained using three external instruments; namely, the number of bank branches and the number of ATMs in the sending country both interacted with the migrant stock in the initial year of the sample period, and the speed of remitting. We test for weak instruments and for the exclusion restriction of the validity of the instruments used. The results of the tests indicate that the instruments are not weak (the F test of the first-step regression is higher than 10). The exclusion restriction cannot be rejected since the Hansen test probability is higher than 0.10 .

Next, we control for a number of macroeconomic, financial and institutional factors in both the sending and the receiving countries. Column (2) in Table 3 shows estimations including indicators

${ }^{7}$ Note the reduction in the number of observations in Table 3 due to missing data in the external instruments used. 
T A B L E 2 Remittances and transaction cost: baseline estimations

\begin{tabular}{|c|c|c|c|c|c|c|}
\hline $\begin{array}{l}\text { Dependent variable: In } \\
\text { (Remit) }\end{array}$ & (1) FE & (2) CRE & (3) $\mathbf{F E}$ & (4) CRE & (5) $\mathrm{FE}$ & $\begin{array}{l}\text { (6) } \\
\text { CRE }\end{array}$ \\
\hline \multicolumn{7}{|l|}{ Explanatory variables } \\
\hline \multirow[t]{2}{*}{$\ln ($ Trans.cost 200) } & & & $-0.24^{* *}$ & $-0.24^{* *}$ & $-0.22^{* * * *}$ & $-0.22^{* * * *}$ \\
\hline & & & $(0.09)$ & $(0.09)$ & $(0.08)$ & $(0.08)$ \\
\hline \multirow[t]{2}{*}{$\ln ($ Distance $)$} & & 0.02 & & 0.02 & & 0.02 \\
\hline & & $(0.11)$ & & $(0.11)$ & & $(0.11)$ \\
\hline \multirow[t]{2}{*}{$\ln \left(G D P \_P P P\right)_{i}$} & 0.85 & 0.85 & 1.22 & 1.22 & 0.55 & 0.55 \\
\hline & $(0.71)$ & $(0.72)$ & $(0.81)$ & $(0.81)$ & $(0.73)$ & $(0.73)$ \\
\hline \multirow[t]{2}{*}{$\ln (\text { GDP_PPP })_{j}$} & 0.30 & 0.30 & 0.41 & 0.41 & $0.96^{* * *}$ & $0.96^{* * *}$ \\
\hline & $(0.22)$ & $(0.22)$ & $(0.29)$ & $(0.29)$ & $(0.31)$ & $(0.32)$ \\
\hline \multirow[t]{2}{*}{$\ln$ (Stock of migrants) } & $0.20^{*}$ & $0.20^{*}$ & $0.23^{*}$ & $0.23^{*}$ & $0.29^{* *}$ & $0.29^{* * *}$ \\
\hline & $(0.11)$ & $(0.11)$ & $(0.12)$ & $(0.13)$ & $(0.14)$ & $(0.14)$ \\
\hline \multirow[t]{2}{*}{ Border } & & 0.34 & & 0.08 & & -0.01 \\
\hline & & $(0.37)$ & & $(0.29)$ & & $(0.35)$ \\
\hline \multirow[t]{2}{*}{ Language } & & 0.03 & & 0.13 & & 0.11 \\
\hline & & $(0.16)$ & & $(0.16)$ & & $(0.16)$ \\
\hline \multirow[t]{2}{*}{ Colony } & & 0.09 & & -0.04 & & -0.27 \\
\hline & & $(0.21)$ & & $(0.21)$ & & $(0.20)$ \\
\hline \multirow[t]{2}{*}{$\ln ($ Bil. exchange rate) } & & & & & $0.79^{* * *}$ & $0.79^{* * *}$ \\
\hline & & & & & $(0.32)$ & $(0.32)$ \\
\hline \multirow[t]{2}{*}{ Exc. rate $s t a b_{i}$} & -0.12 & -0.12 & -0.18 & -0.18 & & \\
\hline & $(0.13)$ & $(0.14)$ & $(0.15)$ & $(0.15)$ & & \\
\hline \multirow[t]{2}{*}{ Exc. rate $s t a b_{j}$} & $0.37^{* *}$ & $0.37^{* *}$ & $0.46^{* * *}$ & $0.46^{* * *}$ & & \\
\hline & $(0.14)$ & $(0.15)$ & $(0.16)$ & $(0.17)$ & & \\
\hline Observations & 1,071 & 1,071 & 924 & 924 & 981 & 981 \\
\hline$R^{2}$ & 0.407 & 0.707 & 0.418 & 0.714 & 0.300 & 0.706 \\
\hline Number of pairs & 217 & 217 & 217 & 217 & 232 & 232 \\
\hline Pair FE (fixed or random) & YES & YES & YES & YES & YES & YES \\
\hline Year FE & YES & YES & YES & YES & YES & YES \\
\hline
\end{tabular}

Robust standard errors in parentheses. All models regress the natural log of bilateral remittances. Models 1, 3 and 5 show two-way fixed effects estimates. Columns 2, 4 and 6 show estimates using the CRE approach.

$* * * p<0.01$

$* * p<0.05$,

$* p<0.1$.

for exchange rate stability in origin and destination countries. The results show that the impact of exchange rate stability on remittances is statistically significant in the case of the receiving country, but is not always for the sending country. In other words, a country with a stable exchange rate receives higher remittance inflows, while the stability of the sending-country exchange rate does not play a significant role in driving remittances.

In Column (3), we control for the degree of financial development in the countries involved in the transaction. A competitive financial system in either the migrant's home or host country facilitates 
T A B L E 3 Remittances and transaction cost (USD 200): FE-IV estimations

\begin{tabular}{|c|c|c|c|c|}
\hline $\begin{array}{l}\text { Dependent variable: In } \\
\text { (Remit) }\end{array}$ & (1) & (2) & (3) & (4) \\
\hline \multicolumn{5}{|l|}{ Explanatory variables } \\
\hline \multirow{2}{*}{$\ln ($ Trans. Cost 200) } & $-1.57^{* *}$ & $-1.62^{* * *}$ & $-1.54^{* * *}$ & $-0.91^{* *}$ \\
\hline & $(0.63)$ & $(0.61)$ & $(0.58)$ & $(0.44)$ \\
\hline \multirow[t]{2}{*}{$\ln \left(G D P \_P P P\right)_{i}$} & $1.55^{*}$ & $1.72^{*}$ & $2.72^{* * * *}$ & $3.40^{* * *}$ \\
\hline & $(0.81)$ & $(0.96)$ & $(1.02)$ & $(0.89)$ \\
\hline \multirow{2}{*}{$\ln \left(\mathrm{GDP} \_P P P\right)_{\mathrm{j}}$} & $1.09^{*}$ & 0.71 & 0.77 & 0.50 \\
\hline & $(0.62)$ & $(0.64)$ & $(0.69)$ & $(0.64)$ \\
\hline \multirow[t]{2}{*}{$\ln$ (Stock of migrants) } & $0.66^{* * *}$ & $0.59^{* *}$ & $0.56^{* *}$ & $0.44^{* *}$ \\
\hline & $(0.22)$ & $(0.23)$ & $(0.22)$ & $(0.18)$ \\
\hline \multirow[t]{2}{*}{ Exc. Rate $s t a b_{i}$} & & $0.97^{*}$ & 0.83 & 0.05 \\
\hline & & $(0.58)$ & $(0.51)$ & $(0.48)$ \\
\hline \multirow[t]{2}{*}{ Exc. Rate $s t a b_{j}$} & & $0.57^{* *}$ & $0.74^{* * * *}$ & $0.65^{* *}$ \\
\hline & & $(0.29)$ & $(0.28)$ & $(0.27)$ \\
\hline \multirow[t]{2}{*}{$\ln \left(\right.$ liquid liabilities to $G D P_{i}$ ) } & & & $2.31^{* * * *}$ & $2.80^{* * * *}$ \\
\hline & & & $(0.73)$ & $(0.65)$ \\
\hline \multirow[t]{2}{*}{$\ln$ (liquid liabilities to $G D P_{j}$ ) } & & & $0.97^{* * *}$ & $0.79^{* *}$ \\
\hline & & & $(0.40)$ & $(0.33)$ \\
\hline \multirow[t]{2}{*}{ Instit $_{i}$} & & & & $-0.81^{* * *}$ \\
\hline & & & & $(0.23)$ \\
\hline \multirow[t]{2}{*}{ Instit $_{\mathrm{j}}$} & & & & -0.22 \\
\hline & & & & $(0.30)$ \\
\hline Observations & 413 & 383 & 362 & 362 \\
\hline Number of pairs & 92 & 86 & 78 & 78 \\
\hline Hansen (Prob) & 0.548 & 0.315 & 0.345 & 0.606 \\
\hline Pair FE & YES & YES & YES & YES \\
\hline Time FE & YES & YES & YES & YES \\
\hline
\end{tabular}

Robust standard errors in parentheses. Dependent variable: natural log of bilateral remittances. The models use a two-step GMM with fixed effects (stata command xtivreg2). 2. Instruments include instr1 = bank_bra_hos * migst2011, instr2 = atm_hos * migst2011 and instr3 $=$ speed of transfer.

$* * * p<0.01$,

$* * p<0.05$

$* p<0.1$.

formal fund transfers (Acosta et al., 2009; Giuliano \& Ruiz-Arranz, 2009; Mallick, 2017; Ratha, 2005; Suro et al., 2002). Recipient countries with well-developed and technologically advanced financial institutions attract larger remittance inflows through formal channels (Kemegue et al., 2011).

According to some authors, one of the reasons why remittance inflows to SSA have remained largely informal is the limited presence of the formal financial sector (Mohapatra \& Ratha, 2011; Page \& Plaza, 2006). Following King and Levine (1993) and Bettin and Zazzaro (2012), we use the ratio of liquid liabilities of the banking sector to GDP (also called broad money or M3) as a proxy for the financial depth of the country. In line with the literature, we find a positive effect of financial sector 
depth on remittance inflows. The effect is significant for the financial sector of both the sending and receiving countries, although the impact is stronger in the case of the sending countries.

Moreover, we add controls for the quality of institutions. Column (4) shows the results of the estimation including political stability as an additional control variable. Stability of the political setup can influence remittance inflows in different ways. On the one hand, improvements in government effectiveness can reinforce migrants' confidence in the country's institutions and increase investmentmotivated remittances (Lartey \& Mengova, 2016). On the other hand, political instability, social unrest and conflict situations can encourage migrants to contribute to the stay-behind household members' financial well-being, the so-called altruistic motive for remittances (Mughal \& Anwar, 2015). We use the ICRG political stability index based on indicators of government stability, investment profile and socioeconomic conditions. We find that a lower level of stability is associated with a rise in remittances. The association, however, is significant only for the sending countries. In all the estimations with additional controls (Columns 2-4), the coefficient for remittance cost retains its negative sign with significance at the 1 or $5 \%$ level. The elasticities range from 0.91 to 1.62 .

\section{5 | ROBUSTNESS CHECKS}

Table 4 presents a number of additional robustness checks. Column (1) shows the results of estimations regressing remittance flows on the cost of remitting USD 500 instead of USD 200, while column (2) shows results from regressions that use the cost of remitting USD 500 in levels (without taking natural $\operatorname{logs}$ ). As before, the signs of the transaction cost coefficients are negative and the magnitudes of the coefficients are not dissimilar when they are made comparable. The association between remittance amount and cost of remitting USD 500, however, is not statistically significant. This finding indicates that transfer fees are a significant determinant of the amount of money the migrants send, but only for relatively small amounts. For larger amounts, cost does not seem to be a constraint. Money transfer services, especially those offered by banks, charge fixed fees which prove exorbitant for small remittances. Another possible explanation lies in the diverse uses to which different amounts of remittances are dedicated. A large number of international migrants send small amounts to their families back home on a frequent basis. These remittances are often meant to cover the households' everyday needs and are highly sensitive to the costs incurred. However, some migrants, usually those based permanently in the host countries, remit large sums to their countries of origin. These infrequent transfers are less sensitive to transfer fees and are meant for investing in real estate or other commercial ventures, or contributing to philanthropic causes.

In columns (3) to (5), we present three additional alternative estimations to check the robustness of our main findings. Column (3) uses the current stock of immigrants as the interacted instrument instead of the initial migrant stock. Columns (4) and (5) replace remittance with remittance per migrant and remittance per capita as dependent variables, respectively. Once again, the association in all three estimations remains significant with a negative sign. In fact, the coefficients of the target variable, transaction cost, in columns (4) and (5) show slightly higher magnitude and lower standard errors than the baseline coefficients in column (3).

Another robustness test consists of splitting the sample according to the level of bilateral remittances and comparing the impact of transaction costs on remittances across sub-samples (see Table 5). We test whether high-volume corridors drive the results by restricting the sample to three (columns 1 and 2) and five (columns 3 and 4) major corridors for each recipient country in the sample. The results indicate that the coefficient of remittance cost remains negative and significant. The results for the top three and top five corridors are very similar. Conversely, when major corridors are excluded from the 
T A B L E 4 Remittances and transaction cost: additional estimates

\begin{tabular}{|c|c|c|c|c|c|}
\hline & (1) & (2) & (3) & (4) & (5) \\
\hline $\begin{array}{c}\text { Dependent } \\
\text { variables }\end{array}$ & $\ln$ (Remit) & $\ln ($ Remit $)$ & $\ln ($ Remit $)$ & Remit /Mig. & Remit/Pop. \\
\hline \multicolumn{6}{|c|}{ Explanatory variables } \\
\hline \multirow[t]{2}{*}{$\ln ($ Trans. cost 200) } & & & $-0.710^{*}$ & $-0.985^{* *}$ & $-0.872^{* *}$ \\
\hline & & & $(0.410)$ & $(0.500)$ & $(0.439)$ \\
\hline \multirow[t]{2}{*}{$\ln ($ Trans. cost 500) } & -1.444 & & & & \\
\hline & (1.476) & & & & \\
\hline \multirow{2}{*}{$\begin{array}{l}\text { Trans. cost } 500 \\
(\%)\end{array}$} & & -0.0950 & & & \\
\hline & & $(0.152)$ & & & \\
\hline \multirow[t]{2}{*}{$\ln (\text { GDP_PPP })_{i}$} & $4.333^{* * *}$ & $3.344^{* * *}$ & $3.204^{* * *}$ & $2.632^{* * *}$ & $3.264^{* * *}$ \\
\hline & $(1.550)$ & $(0.850)$ & $(0.840)$ & $(0.946)$ & $(0.881)$ \\
\hline \multirow{2}{*}{$\ln (\text { GDP_PPP })_{j}$} & 1.233 & 0.652 & 0.385 & 0.281 & 0.463 \\
\hline & (1.116) & $(0.718)$ & $(0.624)$ & $(0.656)$ & $(0.633)$ \\
\hline \multirow{2}{*}{$\begin{array}{l}\ln (\text { Stock of } \\
\text { migrants })\end{array}$} & $0.586^{*}$ & $0.434^{* *}$ & $0.376^{* *}$ & & $0.421^{* *}$ \\
\hline & $(0.325)$ & $(0.220)$ & $(0.168)$ & & $(0.176)$ \\
\hline \multirow[t]{2}{*}{ Exc. rate $s t a b_{i}$} & 0.00556 & -0.258 & 0.0465 & 0.267 & 0.0909 \\
\hline & $(0.690)$ & $(0.496)$ & $(0.479)$ & $(0.555)$ & $(0.483)$ \\
\hline \multirow[t]{2}{*}{ Exc. rate $s t a b_{j}$} & $0.675^{*}$ & $0.590^{*}$ & $0.589^{* *}$ & $0.783^{* * *}$ & $0.651^{* *}$ \\
\hline & $(0.343)$ & $(0.322)$ & $(0.278)$ & $(0.282)$ & $(0.275)$ \\
\hline \multirow{2}{*}{$\begin{array}{l}\ln (\text { liquid liabilities } \\
\text { to } G D P_{i} \text { ) }\end{array}$} & $3.227^{* * *}$ & $2.619^{* * *}$ & $2.746^{* * *}$ & $2.167^{* * *}$ & $2.632^{* * *}$ \\
\hline & $(0.996)$ & $(0.607)$ & $(0.624)$ & $(0.676)$ & $(0.641)$ \\
\hline \multirow{2}{*}{$\begin{array}{l}\ln (\text { liquid liabilities } \\
\text { to } G D P_{j} \text { ) }\end{array}$} & 1.007 & 0.653 & $0.676^{* *}$ & $0.979^{* * *}$ & $0.782^{* *}$ \\
\hline & $(0.664)$ & $(0.469)$ & $(0.311)$ & $(0.333)$ & $(0.321)$ \\
\hline \multirow[t]{2}{*}{ Instit $_{\mathrm{i}}$} & $-1.398^{* *}$ & $-0.951^{* * *}$ & $-0.770^{* * *}$ & $-0.709^{* * *}$ & $-0.762^{* * *}$ \\
\hline & $(0.687)$ & $(0.351)$ & $(0.223)$ & $(0.242)$ & $(0.227)$ \\
\hline \multirow[t]{2}{*}{ Instit $_{j}$} & -0.339 & -0.329 & -0.266 & -0.410 & -0.224 \\
\hline & $(0.383)$ & $(0.292)$ & $(0.307)$ & $(0.333)$ & $(0.297)$ \\
\hline Observations & 362 & 362 & 362 & 362 & 362 \\
\hline Number of pairs & 78 & 78 & 78 & 78 & 78 \\
\hline Pair FE & YES & YES & YES & YES & YES \\
\hline Time FE & YES & YES & YES & YES & YES \\
\hline Hansen (prob.) & 0.279 & 0.108 & 0.180 & 0.186 & 0.619 \\
\hline
\end{tabular}

Robust standard errors in parentheses. The models use a two-step GMM with fixed effects (stata command xtivreg2). Instruments include: instr1 = bank_bra_hos * migst2011, instr2 = atm_hos * migst2011, and instr3 = speed of transfer, except for Model 3 which uses the current stock of immigrants as the interacted instrument instead of initial migrant stock. Model 1 regresses remittance flows on the cost of remitting USD 500 instead of USD 200. Model 2 regresses remittances on the cost of remitting USD 500 without taking logarithms. Models 4 and 5 use remittances per migrant and per capita remittances as dependent variables, respectively.

$* * * p<0.01$,

$* * p<0.05$,

$* p<0.10$. 
T A B L E 5 Sub-sample regressions for top versus non-top remittance corridors

\begin{tabular}{|c|c|c|c|c|c|c|}
\hline $\begin{array}{l}\text { Dependent variable: In } \\
\text { (Remit) }\end{array}$ & (1) & (2) & (3) & (4) & (5) & (6) \\
\hline \multicolumn{7}{|l|}{ Explanatory variables } \\
\hline $\ln ($ Trans. cost 200$)$ & $\begin{array}{l}-0.65^{* * *} \\
(0.21)\end{array}$ & $\begin{array}{l}-0.50 \\
(0.78)\end{array}$ & $\begin{array}{l}-0.76^{* * *} \\
(0.28)\end{array}$ & $\begin{array}{l}-0.02 \\
(0.23)\end{array}$ & $\begin{array}{l}-0.62^{* *} \\
(0.27)\end{array}$ & $\begin{array}{l}-0.46 \\
(0.44)\end{array}$ \\
\hline $\ln \left(G D P \_P P P\right)_{i}$ & $\begin{array}{l}6.53^{* * *} \\
(1.58)\end{array}$ & $\begin{array}{l}1.30 \\
(1.25)\end{array}$ & $\begin{array}{l}6.15^{* * *} \\
(1.37)\end{array}$ & $\begin{array}{l}1.30^{*} \\
(0.71)\end{array}$ & $\begin{array}{l}2.80^{* * *} \\
(0.69)\end{array}$ & $\begin{array}{l}10.69^{* *} \\
(4.38)\end{array}$ \\
\hline $\ln \left(G D P \_P P P\right)_{j}$ & $\begin{array}{l}1.37 \\
(0.86)\end{array}$ & $\begin{array}{l}-1.06 \\
(1.21)\end{array}$ & $\begin{array}{l}0.91 \\
(0.74)\end{array}$ & $\begin{array}{l}-0.85 \\
(0.65)\end{array}$ & $\begin{array}{l}-0.17 \\
(0.51)\end{array}$ & $\begin{array}{l}-0.19 \\
(1.17)\end{array}$ \\
\hline Exc. rate $s t a b_{i}$ & $\begin{array}{l}-0.34 \\
(0.56)\end{array}$ & $\begin{array}{l}0.02 \\
(0.80)\end{array}$ & $\begin{array}{l}-0.12 \\
(0.51)\end{array}$ & $\begin{array}{l}-0.10 \\
(0.32)\end{array}$ & $\begin{array}{l}0.22 \\
(0.35)\end{array}$ & $\begin{array}{l}-0.91 \\
(1.04)\end{array}$ \\
\hline Exc. rate $s t a b_{j}$ & $\begin{array}{l}0.65^{* *} \\
(0.30)\end{array}$ & $\begin{array}{l}0.64 \\
(0.57)\end{array}$ & $\begin{array}{l}0.68^{* * *} \\
(0.30)\end{array}$ & $\begin{array}{l}0.32^{*} \\
(0.19)\end{array}$ & $\begin{array}{l}0.25^{*} \\
(0.14)\end{array}$ & $\begin{array}{l}0.94^{* *} \\
(0.43)\end{array}$ \\
\hline $\begin{array}{l}\ln (\text { liquid liabilities to } \\
\left.\mathrm{GDP}_{\mathrm{i}}\right)\end{array}$ & $\begin{array}{l}3.70^{* * *} \\
(0.89)\end{array}$ & $\begin{array}{l}1.12 \\
(1.38)\end{array}$ & $\begin{array}{l}3.43^{* * *} \\
(0.72)\end{array}$ & $\begin{array}{l}1.45^{*} \\
(0.85)\end{array}$ & $\begin{array}{l}2.27^{* * * *} \\
(0.57)\end{array}$ & $\begin{array}{l}6.91^{* * *} \\
(2.57)\end{array}$ \\
\hline $\begin{array}{l}\ln (\text { liquid liabilities to } \\
\text { GDP }_{\mathrm{j}} \text { ) }\end{array}$ & $\begin{array}{l}0.71^{* *} \\
(0.28)\end{array}$ & $\begin{array}{l}0.47 \\
(0.80)\end{array}$ & $\begin{array}{l}0.84 * * \\
(0.40)\end{array}$ & $\begin{array}{l}0.17 \\
(0.25)\end{array}$ & $\begin{array}{l}0.54^{* * *} \\
(0.19)\end{array}$ & $\begin{array}{l}1.53 \\
(1.20)\end{array}$ \\
\hline Instit $_{i}$ & $\begin{array}{l}-1.02^{* * *} \\
(0.27)\end{array}$ & $\begin{array}{l}-0.35 \\
(0.36)\end{array}$ & $\begin{array}{l}-0.94^{\text {*** }} \\
(0.27)\end{array}$ & $\begin{array}{l}-0.32^{*} \\
(0.17)\end{array}$ & $\begin{array}{l}-0.34^{* *} \\
(0.15)\end{array}$ & $\begin{array}{l}-1.93^{* * * *} \\
(0.67)\end{array}$ \\
\hline Instit $_{j}$ & $\begin{array}{l}0.26 \\
(0.36)\end{array}$ & $\begin{array}{l}-0.61 \\
(0.52)\end{array}$ & $\begin{array}{l}0.22 \\
(0.35)\end{array}$ & $\begin{array}{l}-0.25 \\
(0.31)\end{array}$ & $\begin{array}{l}-0.01 \\
(0.23)\end{array}$ & $\begin{array}{l}-0.01 \\
(0.67)\end{array}$ \\
\hline Observations & 230 & 147 & 283 & 94 & 250 & 127 \\
\hline Number of pairs & 50 & 30 & 62 & 18 & 50 & 30 \\
\hline Pair FE & YES & YES & YES & YES & YES & YES \\
\hline Time FE & YES & YES & YES & YES & YES & YES \\
\hline Hansen (prob.) & 0.232 & 0.289 & 0.119 & 0.293 & 0.142 & 0.0301 \\
\hline
\end{tabular}

Robust standard errors in parentheses. The models use a two-step GMM with fixed effects (stata command xtivreg2). Instruments include: instr1 = bank_bra_hos * migst2011, instr2 = atm_hos * migst2011, and instr3 = speed of transfer. Model 1 presents the results for the top three corridors, while model 2 excludes these three. Model 3 includes only the top five corridors and model 4 excludes them. Models 5 and 6 are estimated for above- and below-median remittances, respectively.

$* * * p<0.01$,

$* * p<0.05$,

$* p<0.1$.

sample, the estimates of the target coefficients are not found to be statistically significant, indicating a lack of evidence to support the relevance of remittance costs for smaller corridors.

As a further robustness check, we examine whether or not the remittance-enhancing effect of a reduction in transfer charges is valid for receiving countries regardless of the size of remittance inflows. In our dataset, the median amount of remittances received was USD 329.42 million. Columns (5) and (6) in Table 5 show estimations carried out on the sub-samples of receiving countries with above- and below-median remittance inflows, respectively. Overall, the results reinforce our previous findings. More specifically, we find that the impact of remittance costs is negative for both groups of countries. However, it is significant only for the countries receiving above-median amounts of remittances, suggesting that the costs involved fall once remittance flows reach sufficient volumes. 


\section{CONCLUSIONS}

One of the targets of SDG 10 is to bring down the cost of remitting to $3 \%$ globally by 2030 , that is, less than half of today's level. In this study, we examine the extent to which reductions in remittance costs drive formal remittance flows. We used data on bilateral remittances for 30 sending and 75 receiving countries for the period 2011-2017 to estimate a gravity model of remittances applying panel data and instrumental variables approaches. The main results suggest that a reduction in remittance costs has a substantial impact on the amount of remittances received by developing countries. In particular, we found that a $1 \%$ drop in the cost of transferring USD 200 is associated with as much as a $1.6 \%$ increase in remittance inflows. The magnitude of the impact is substantially lower when using standard panel data techniques that do not address endogeneity issues. Moreover, the beneficial effect found for the transfer of small amounts does not extend to larger ones, indicating the presence of a scale effect. We also find that physical distance between the two countries - the indicator commonly used in the literature to proxy for transaction cost—-does not significantly affect remittance flows; it can therefore be considered a poor proxy for transaction cost.

Given that remittances are an economic lifeline for many developing economies, the main findings highlight the need for sustained efforts in the international policy arena to reduce transaction costs. Reducing the cost of remitting from the current level of $7 \%$ to the $3 \%$ target would lead to almost double the volume of formal remittances. If this cost reduction can be achieved, international migration would become a more effective tool for fostering development by ensuring that stay-behind households in developing countries receive a greater share of the money sent by the migrant abroad. In addition, enhancing migrants' access to formal banking services will not only add to the depth of formal financial markets, but also improve the receiving country's balance of payments.

Lowering the cost of remitting and thereby increasing remittance inflows can additionally have an impact in terms of reducing economic inequalities. We found that the remittance-increasing effect of cost reductions is mainly observed for small transfers. Since such transfers tend to be made by temporary, low-income migrant workers sending money home on a frequent basis, lower remittance costs will allow them to remit more through formal channels. Governments can play a key role in this regard by promoting competition among the money transfer operators and banking institutions. This is especially critical in contexts where anti-money laundering and terror-financing regulations have raised the cost of monitoring clients and their financial transactions, which particularly affects small financial institutions. Therefore, ensuring a level-playing field for all the players in the formal financial market can help keep costs down. Another policy approach to reduce the cost of remitting could consist of improving the transparency and comparability of remittance services pricing, for example by maintaining an updated online register of the prices charged for various remittance products. Finally, providing better information to migrants and their stay-behind families about these pricing mechanisms, as well as helping them to make more informed decisions, can increase the use of lesscostly remittance services.

\section{Acknowledgements}

The authors gratefully acknowledge the support and comments during a seminar at the Korean Institute of International Economic Policy (KIEP), South Korea and the Georg August University, Goettingen, Germany.

\section{REFERENCES}

Acosta, P. A., Lartey, E. K., \& Mandelman, F. S. (2009). Remittances and the Dutch disease. Journal of International Economics, 79(1), 102-116. 
Adams, R. H. Jr (2009). The determinants of international remittances in developing countries. World Development, 37(1), 93-103.

Ahmed, J., \& Martínez-Zarzoso, I. (2016). Do transfer costs matter for foreign remittances? Economics: the OpenAccess, Open-Assessment E-Journal, 10(2016-4), 1-36.

Ajide, K. B., \& Raheem, I. D. (2016). The institutional quality impact on remittances in the ECOWAS sub-region. African Development Review, 28(4), 462-481.

Altonji, J. G., \& Card, D. (1991). The effects of immigration on the labor market outcomes of less-skilled natives. Immigration, trade, and the labor market (pp. 201-234). :University of Chicago Press.

Amuedo-Dorantes, C., \& Pozo, S. (2004). Workers' remittances and the real exchange rate: A paradox of gifts. World Development, 32(8), 1407-1417.

Anwar, A., \& Mughal, M. (2012). Motives to remit: Some microeconomic evidence from Pakistan. Economics Bulletin, Access Economics, 32(1), 84-95.

Azizi, S. (2019). Why do migrants remit? The World Economy, 42(2), 429-452.

Baum, C. F., Schaffer, M. E., \& Stillman, S. (2003). Instrumental variables and GMM: Estimation and testing. The Stata Journal, 3, 1-31.

Baum, C. F., Schaffer, M. E., \& Stillman, S. (2007). Enhanced routines for instrumental variables/generalized method of moments estimation and testing. The Stata Journal, 7, 465-506.

Beck, T., \& Martínez Pería, M. S. (2011). What explains the price of remittances? An examination across 119 country corridors. World Bank Economic Review, 25(1), 105-131.

Beine, M., Docquier, F., \& Rapoport, H. (2008). Brain drain and human capital formation in developing countries: Winners and losers. The Economic Journal, 118(528), 631-652.

Bénassy-Quéré, A., Coupet, M., \& Mayer, T. (2007). Institutional determinants of foreign direct investment. The World Economy, 30(5), 764-782.

Bettin, G., \& Zazzaro, A. (2012). Remittances and financial development: Substitutes or complements in economic growth? Bulletin of Economic Research, 64(4), 509-536.

Brei, M., \& Von Peter, G. (2018). The distance effect in banking and trade. Journal of International Money and Finance, $81,116-137$.

Card, D. (2001). Immigrant inflows, native outflows, and the local labor market impacts of higher immigration. Journal of Labor Economics, 19(1), 22-64.

Carling, J. (2008). The determinants of migrant remittances. Oxford Review of Economic Policy, 24(3), $581-598$.

Coulibaly, D. (2009). Macroeconomic Determinants of Migrants' Remittances: New Evidence from a panel VAR. Université Panthéon-Sorbonne (Paris 1), Centre d'Economie de la Sorbonne.

Cox, D. (1987). Motives for private income transfers. Journal of Political Economy, 95(3), 508-546. https://doi. org/10.1086/261470

Cox, D., Eser, Z., \& Jimenez, E. (1998). Motives for private transfers over the life cycle: An analytical framework and evidence for Peru. Journal of Development Economics, 55, 5780.

De Sousa, J., \& Duval, L. (2010). Geographic distance and remittances in Romania: Out of sight, out of mind? Economie Internationale, 1, 81-97.

Demekas, D. G., Horváth, B., Ribakova, E., \& Wu, Y. (2005). Foreign direct investment in South Eastern Europe: How (and how much) can policies help? IMF Working Paper 05/110.

El-Sakka, M. I., \& McNabb, R. (1999). The macroeconomic determinants of emigrant remittances. World Development, $27(8), 1493-1502$.

Ezeoha, A. E. (2013). Financial determinants of international remittance flows to the sub-saharan African region. International Migration, 51, e84-e97.

Faini, R. (1994). Workers remittances and the real exchange rate. Journal of Population Economics, 7(2), $235-245$.

Ferriani, F., \& Oddo, G. (2019). More distance, more remittance? Remitting behaviour, travel cost, and the size of the informal channel. Economic Notes: Review of Banking, Finance and Monetary Economics, 48(3), 1-23.

Frankel, J. (2011). Are bilateral remittances countercyclical? Open Economies Review, 22(1), 1-16.

Freund, C., \& Spatafora, N. (2008). Remittances, transaction costs, and informality. Journal of Development Economics, $86(2), 356-366$.

Gibson, J., McKenzie, D., \& Rohorua, H. (2006). How cost elastic are remittances? Evidence from Tongan migrants in New Zealand. Pacific Economic Bulletin, 21(1), 112-128. 
Giuliano, P., \& Ruiz-Arranz, M. (2009). Remittances, financial development, and growth. Journal of Development Economics, 90(1), 144-152.

Hagen-Zanker, J., \& Siegel, M. (2007). The determinants of remittances: A review of the literature. Maastricht Graduate School of Governance. Working Paper MGSoG/2007/WP003.

Higgins, M. L., Hysenbegasi, A., \& Pozo, S. (2004). Exchange-rate uncertainty and workers' remittances. Applied Financial Economics, 14(6), 403-411.

Hysenbegasi, A., \& Pozo, S. (2008). Workers' remittances and currency crises. Well-being and Social Policy Journal/ Bienestary Politica Social.

Ilahi, N., \& Jafarey, S. (1999). Guest worker migration, remittances and the extended family: Evidence from Pakistan. Journal of Development Economics, 58, 485-512.

Johnson, E., \& Whitelaw, E. (1974). Urban-rural income transfers in rural Kenya: An estimated remittance function. Economic Development and Cultural Change, 22, 473-479.

Kakhkharov, J., Akimov, A., \& Rohde, N. (2017). Transaction costs and recorded remittances in the post-Soviet economies: Evidence from a new dataset on bilateral flows. Economic Modelling, 60, 98-107.

Kapur, D. (2004). Remittances: The new development Mantra. United Nations Conference on trade and Development (No. 19). G-24 discussion paper Series.

Kemegue, F. M., Owusu-Sekyere, E., \& van Eyden, R. (2011). What drives remittance inflows to Sub-Saharan Africa: A dynamic panel approach.

King, R. G., \& Levine, R. (1993). Finance and growth: Schumpeter might be right. The Quarterly Journal of Economics, 108(3), 717-737.

Lartey, E. K., \& Mengova, E. (2016). Does institutional quality in developing countries affect remittances? The Journal of Developing Areas, 50(1), 59-76.

Lewer, J. J., \& Van den Berg, H. (2008). A gravity model of immigration. Economics Letters, 99(1), $164-167$.

Lucas, B., \& Stark, O. (1985). Motivations to Remit: Evidence from Botswana. The Journal of Political Economy, 93(5), 901-918.

Lueth, E., \& Ruiz-Arranz, M. (2008). Determinants of bilateral remittance flows. The BE Journal of Macroeconomics, $8(1), 1-21$.

Mallick, H. (2017). Determinants of workers' remittances: An empirical investigation for a panel of eleven developing Asian economies. The World Economy, 40(12), 2875-2900.

Mayda, A. M. (2010). International migration: A panel data analysis of the determinants of bilateral flows. Journal of Population Economics, 23(4), 1249-1274.

McCracken, S., Ramlogan-Dobson, C., \& Stack, M. M. (2017). A gravity model of remittance determinants: evidence from Latin America and the Caribbean. Regional Studies, 51(5), 737-749.

Mohapatra, S., \& Ratha, D. (Eds.) (2011). Remittance markets in Africa. Washington, DC: The World Bank.

Mookerjee, R., \& Roberts, J. (2011). Banking services, transaction costs and international remittance flows. Applied Economics Letters, 18(3), 199-205.

Mughal, M. Y., \& Anwar, A. I. (2015). Do migrant remittances react to bouts of terrorism? Defence and Peace Economics, 26(6), 567-582.

Mundlak, Y. (1978). On the pooling of time series and cross section data. Econometrica, 46(1), 69-85.

Page, J., \& Plaza, S. (2006). Migration remittances and development: A review of global evidence. Journal of African Economies, 15(suppl_2), 245-336.

Portes, R., \& Rey, H. (2005). The determinants of cross-border equity flows. Journal of International Economics, 65(2), 269-296.

Rapoport, H., \& Docquier, F. (2006). The economics of migrants' remittances. Handbook of the Economics of Giving, Altruism and Reciprocity, 2, 1135-1198.

Ratha, D. (2005). Workers' remittances: an important and stable source of external development finance. Remittances: Development impact and future prospects, 19-51.

Ratha, D. (2006). Economic implications of remittances and migration. World Bank.

Ratha, D., De, S., Schuettler, K., Seshan, G., \& Desiree Yameogo, N. (2018). Migration and development: Recent developments and outlook. Migration and Development Brief 29, World Bank.

Ratha, D., \& Riedberg, J. (2005). On reducing remittance costs. Unpublished paper. Development Research Group, World Bank, Washington, DC.

Ratha, D., \& Shaw, W. (2007). South-South migration and remittances. Washington, DC: The World Bank. 
Ruiz, I., \& Vargas-Silva, C. (2009). To send, or not to send: That is the question. A review of the literature on workers' remittances. Journal of Business Strategies, 26(1), 73.

Schiopu, I., \& Siegfried, N. (2006). Determinants of workers' remittances: Evidence from the European Neighbouring Region, (No. 688). ECB Working Paper.

Siddique, A., Selvanathan, E. A., \& Selvanathan, S. (2012). Remittances and economic growth: Empirical evidence from Bangladesh, India and Sri Lanka. Journal of Development Studies, 48(8), 1045-1062.

Singh, R. J., Haacker, M., Lee, K. W., \& Le Goff, M. (2011). Determinants and macroeconomic impact of remittances in Sub-Saharan Africa. Journal of African Economies, 20(2), 312-340.

Solimano, A. (2003). Workers remittances to the Andean region: Mechanisms, costs and development impact. In Multilateral investment fund-IDB's conference on remittances and development. Quito-Ecuador (pp. 1-47).

Stark, O., \& Lucas, R. (1988). Migration, remittances and the family. Economic Development and Cultural Change, $36,465-481$.

Suro, R., Bendixen, S., Lowell, B. L., \& Benavides, D. C. (2002). Billions in motion: Latino immigrants, remittances, and banking. Inter-American Development Bank.

Vargas-Silva, C., \& Huang, P. (2006). Macroeconomic determinants of workers' remittances: Host versus home country's economic conditions. Journal of International Trade \& Economic Development, 15(1), 81-99.

Wooldridge, J. M. (2010). Correlated random effects models with unbalanced panels. Michigan State University, Department of Economics.

World Bank (2012). Migration and development brief 19. Migration and Remittances Unit, Development Prospects Group.

World Bank (2019a). World development indicators.

World Bank (2019b). Remittance prices worldwide, making markets more transparent. World Bank.

Yang, D. (2011). Migrant remittances. Journal of Economic Perspectives, 25(3), 129-152. 


\section{APPENDIX 1}

TA B LE A 1 Definition of variables and sources of data

$\begin{array}{ll}\text { Variable } & \text { Definition } \\ \begin{array}{l}\text { Bilateral } \\ \text { remittances }\end{array} & \text { We take remittances received by country } i \text { from country } j \text { in current US } \\ \text { (Current } & \text { dollars in a given period. The Ratha and Shaw (2007) method used for } \\ \text { USD): Remit } & \begin{array}{l}\text { the construction of the Bilateral Remittance Matrix involves allocating a } \\ \text { estimated in the Bilateral Migration Matrix, adjusting for the migrant- }\end{array} \\ & \text { sending and receiving countries' per capita income. The World Bank } \\ & \text { uses two datasets to construct the Bilateral Remittance Matrix. The first } \\ & \text { is the UN Population Division estimates of migrant stock by country of } \\ & \text { origin and destination, also used by this tool. The second dataset used in } \\ & \text { the construction of the Bilateral Remittance Matrix is remittance inflows } \\ & \text { data constructed as the sum of two components of the IMF's Balance } \\ & \text { of Payments Statistics: (i) employee compensation and (ii) personal } \\ & \text { transfers. A country's total remittance inflows in a given year are } \\ & \text { allocated to its emigrant stocks, adjusting for the migrant-sending and } \\ & \text { receiving countries' per capita income. We collect Bilateral Remittance } \\ & \text { Matrix data for each year from 2010 to 2017. To finalise the data for } \\ & \text { bilateral remittances from 2010 to 2017, we first cleaned the data for } \\ & \text { each year before merging them }\end{array}$

Transaction The World Bank Payment Systems Group has compiled the Remittance cost (per Prices Worldwide (RPW) database for the first quarter of 2011 onwards.

Remittances Prices Worldwide, World Bank

\section{sending USD}

200 and USD

500: Trans.

cost 200 and

Trans. cost

500
The source countries are usually developed countries, but there are also some developing countries. To control for exchange rate fluctuations and other changes in fee structures, the data were gathered on the same day in each corridor. The cost data were gathered for 8 to 10 major service providers in each corridor, including both the leading money transfer operators (MTOs) and banks active in the remittances market. For each corridor, firm and product available, the RPW database provides the transfer costs for two amounts of money remitted, that is USD 200 and USD 500. The mean cost of sending USD200 and USD500 is 8.22 and $5.09 \%$, respectively

We convert the data from quarterly to yearly and average the total costs from different MTOs and banks. The total costs charged by a provider are made up of remittance fees as well as the exchange rate spread component. Logically, the transaction cost, as a share of the amount remitted, decreases (though not proportionally) with the amount of money sent, indicating that the cost structure is a mix of fixed and variable costs. In general, the type of product has a similar impact for either amount sent, but the USD 200 transfer has a higher variance. For instance, the variance of USD 200 is 15.18-about three times higher than the variance of sending USD 500, which is 5.51

\section{Geographical}

Distance:

\section{Geogrc}

Distance

\section{Sources}

World Bank

Migration and

Remittances data 
TABLE A 1 (Continued)

\begin{tabular}{|c|c|c|}
\hline Variable & Definition & Sources \\
\hline $\begin{array}{l}\text { Bilateral } \\
\text { migration } \\
\text { stocks: Stock } \\
\text { of migrants }\end{array}$ & $\begin{array}{l}\text { We used two datasets for migrant stocks. The first one is the most } \\
\text { comprehensive source of information on International Migrant Stock } \\
\text { retrieved from the United Nations, Department of Economic and Social } \\
\text { Affairs, Population Division. We take the stock of migrant workers in } \\
\text { the destination country by origin for the years } 2010,2015 \text {, and } 2017 \text {. } \\
\text { The second dataset is compiled by OECD International Migration Data } \\
\text { and covers the period starting from 2001. We gather the data on stock } \\
\text { of foreign-born population by country of birth from } 2010 \text { to } 2017 \text {. The } \\
\text { OECD datasets cover only migrants residing in the OECD. We merge } \\
\text { OECD data on international migrant stock with the UN-DESA dataset } \\
\text { to impute the missing cells }\end{array}$ & $\begin{array}{l}\text { UN-DESA and } \\
\text { OECD }\end{array}$ \\
\hline $\begin{array}{l}\text { GDP (current } \\
\text { USD): } \\
G D P \_P P P\end{array}$ & $\begin{array}{l}\text { GDP at PPP prices is the sum of gross value added by all resident } \\
\text { producers in the economy plus any product taxes and minus any } \\
\text { subsidies not included in the value of the products }\end{array}$ & $\begin{array}{l}\text { World } \\
\text { Development } \\
\text { Indicators, World } \\
\text { Bank }\end{array}$ \\
\hline $\begin{array}{l}\text { Exchange Rate } \\
\text { Stability: } \\
\text { Exc. rate stab }\end{array}$ & $\begin{array}{l}\text { The appreciation or depreciation of a currency against the US dollar over } \\
\text { a calendar year or the most recent } 12 \text {-month period, calculated as a } \\
\text { percentage change. Values are normalised to the range } 0-1\end{array}$ & ICRG \\
\hline $\begin{array}{l}\text { Bilateral } \\
\text { Exchange } \\
\text { rate: Bil. } \\
\text { Exchange } \\
\text { rate }\end{array}$ & $\begin{array}{l}\text { Bilateral exchange rates are expressed in domestic relative to foreign } \\
\text { currency }\end{array}$ & UNCTAD \\
\hline $\begin{array}{l}\text { Common } \\
\text { Colony: } \\
\text { Colony }\end{array}$ & 1 if the countries $i$ and $j$ have ever had a colonial link, 0 otherwise & CEPII \\
\hline $\begin{array}{l}\text { Common } \\
\text { Border: } \\
\text { Border }\end{array}$ & 1 if the countries $i$ and $j$ share a border, 0 otherwise & CEPII \\
\hline $\begin{array}{l}\text { Common } \\
\text { language: } \\
\text { Language }\end{array}$ & 1 if the countries $i$ and $j$ share a common official language, 0 otherwise & CEPII \\
\hline $\begin{array}{l}\text { ATMs per } \\
100,000 \\
\text { adults: } A T M s\end{array}$ & $100,000 *$ Number of ATMs/adult population in the reporting country & $\begin{array}{l}\text { Financial Access } \\
\text { Survey (FAS), } \\
\text { International } \\
\text { Monetary Fund } \\
\text { (IMF) }\end{array}$ \\
\hline $\begin{array}{l}\text { Bank branches } \\
\text { per 100,000 } \\
\text { adults: Bank } \\
\text { Bra }\end{array}$ & $\begin{array}{l}100,000 * \text { reported number of commercial bank branches/adult population } \\
\text { in the reporting country }\end{array}$ & $\begin{array}{l}\text { Financial Access } \\
\text { Survey (FAS), } \\
\text { International } \\
\text { Monetary Fund } \\
\text { (IMF) }\end{array}$ \\
\hline
\end{tabular}


TABLE A 1 (Continued)

\begin{tabular}{|c|c|c|}
\hline Variable & Definition & Sources \\
\hline $\begin{array}{l}\text { Liquid } \\
\text { liabilities } \\
\text { to GDP } \\
\text { (\%): liquid } \\
\text { liabilities to } \\
\text { GDP }_{i}\end{array}$ & $\begin{array}{l}\text { The sum of currency and deposits in the central bank (M0), transferable } \\
\text { deposits and electronic currency (M1), time and savings deposits, } \\
\text { foreign currency transferable deposits, certificates of deposit and } \\
\text { securities repurchase agreements (M2) and traveller's checks, foreign } \\
\text { currency time deposits, commercial paper, and shares of mutual funds } \\
\text { or market funds held by residents }\end{array}$ & $\begin{array}{l}\text { International } \\
\text { Financial } \\
\text { Statistics (IFS), } \\
\text { International } \\
\text { Monetary Fund } \\
\text { (IMF) }\end{array}$ \\
\hline $\begin{array}{l}\text { Institutional } \\
\text { Quality: Instit }\end{array}$ & $\begin{array}{l}\text { Composite index of government stability based on government stability, } \\
\text { investment profile, and socioeconomic condition, with a higher score } \\
\text { indicating more stability. The values are normalised to the range } 0-1\end{array}$ & PRS/ICRG \\
\hline
\end{tabular}


TABLE A 2 List of sending and receiving countries

\begin{tabular}{|c|c|c|c|}
\hline Sending countries & Receiving countries & & \\
\hline Australia & Albania & Kenya & Suriname \\
\hline Austria & Algeria & Kosovo & Swaziland \\
\hline Bahrain & Angola & Kyrgyz Republic & Tajikistan \\
\hline Belgium & Armenia & Lebanon & Tanzania \\
\hline Brazil & Bangladesh & Lesotho & Thailand \\
\hline Canada & Bolivia & Liberia & Togo \\
\hline Chile & Bosnia and Herzegovina & Macedonia & Tonga \\
\hline Czech Republic & Botswana & Madagascar & Tunisia \\
\hline France & Brazil & Malawi & Turkey \\
\hline Germany & Bulgaria & Malaysia & Uganda \\
\hline Israel & Cameroon & Mali & Ukraine \\
\hline Italy & China & Mexico & Vanuatu \\
\hline Japan & Colombia & Moldova & Vietnam \\
\hline Kuwait & Comoros & Morocco & Yemen \\
\hline Malaysia & Costa Rica & Mozambique & Zambia \\
\hline Netherlands & Dominican Republic & Myanmar & \\
\hline New Zealand & Ecuador & Nepal & \\
\hline Norway & Egypt & Nicaragua & \\
\hline Oman & El Salvador & Nigeria & \\
\hline Portugal & Ethiopia & Pakistan & \\
\hline Qatar & Fiji & Peru & \\
\hline Saudi Arabia & Ghana & Philippines & \\
\hline Singapore & Guatemala & Romania & \\
\hline South Africa & Guyana & Rwanda & \\
\hline Spain & Haiti & Samoa & \\
\hline Sweden & Honduras & Senegal & \\
\hline Switzerland & India & Sierra Leone & \\
\hline United Arab Emirates & Indonesia & South Africa & \\
\hline United Kingdom & Jamaica & Sri Lanka & \\
\hline United States & Jordan & Sudan & \\
\hline
\end{tabular}




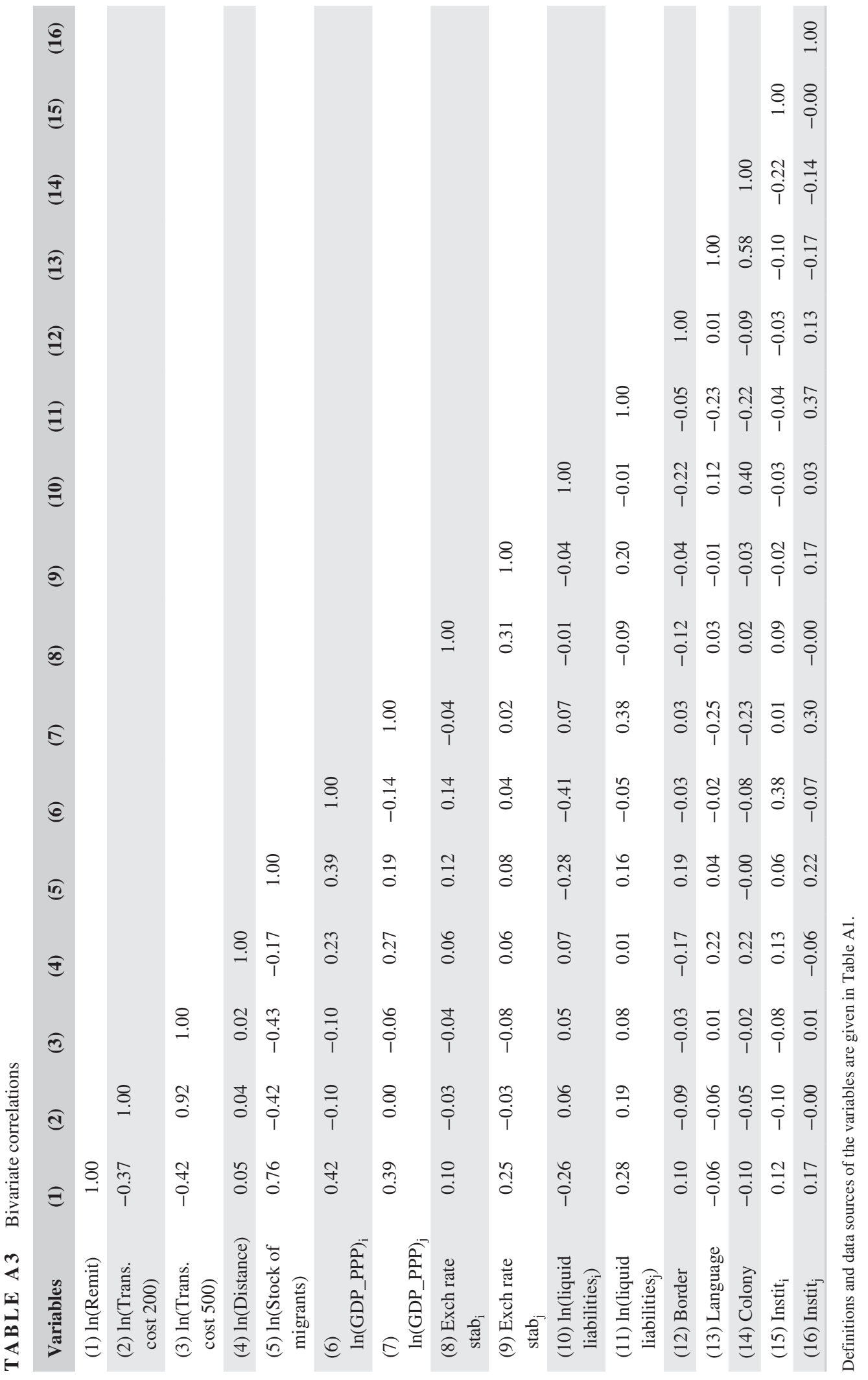


26

WILEY -8 The World Economy

AHMED ET AL.

Transaction Cost and Bilateral Remittances, 2011

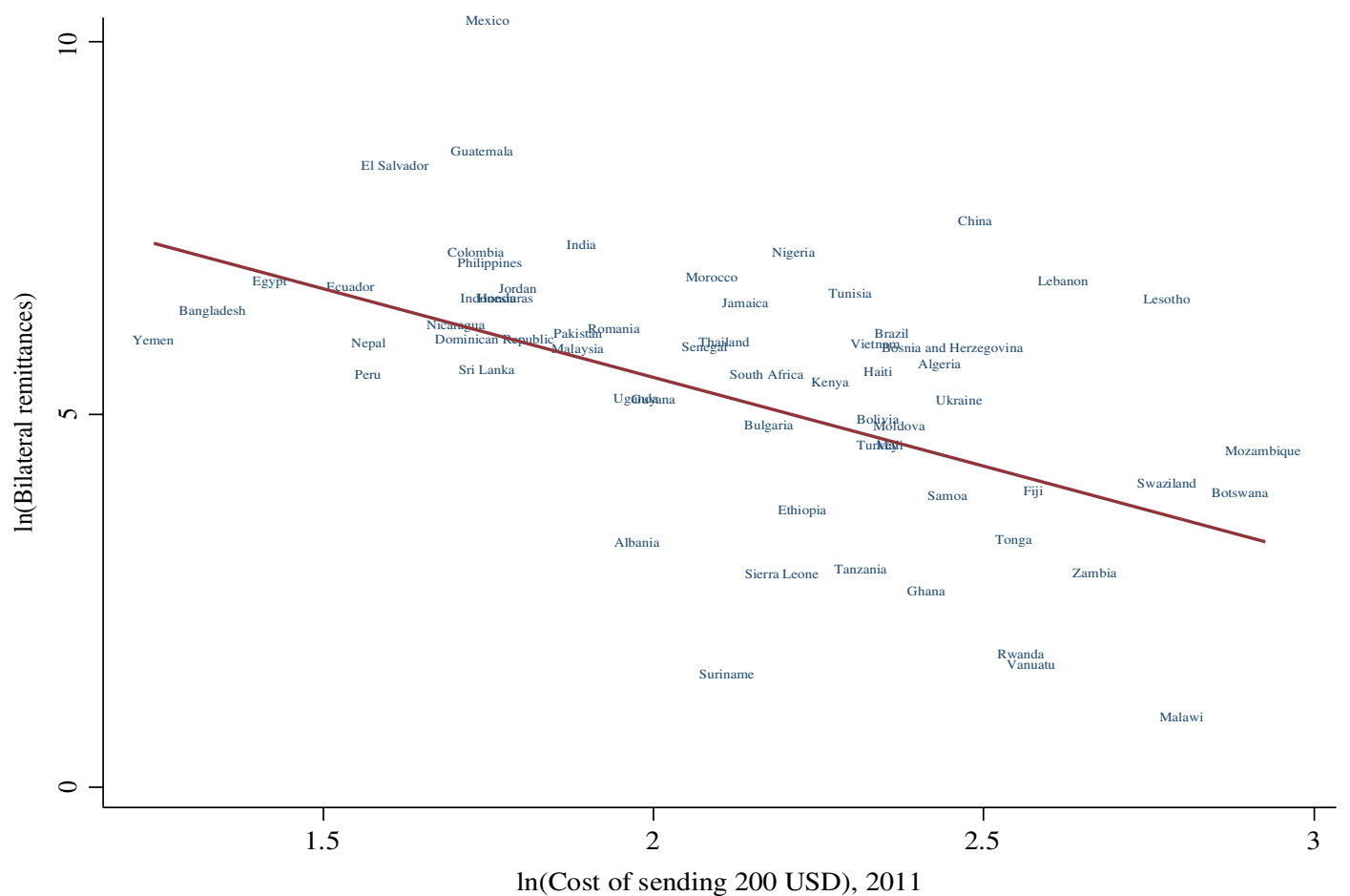

FIGURE A 1 Transaction cost and bilateral remittances, 2011.

SOURCE: REMITTANCE PRICES WORLDWIDE AND REMITTANCES DATA COME FROM THE WORLD BANK. 
Transaction Cost and Bilateral Remittances, 2017

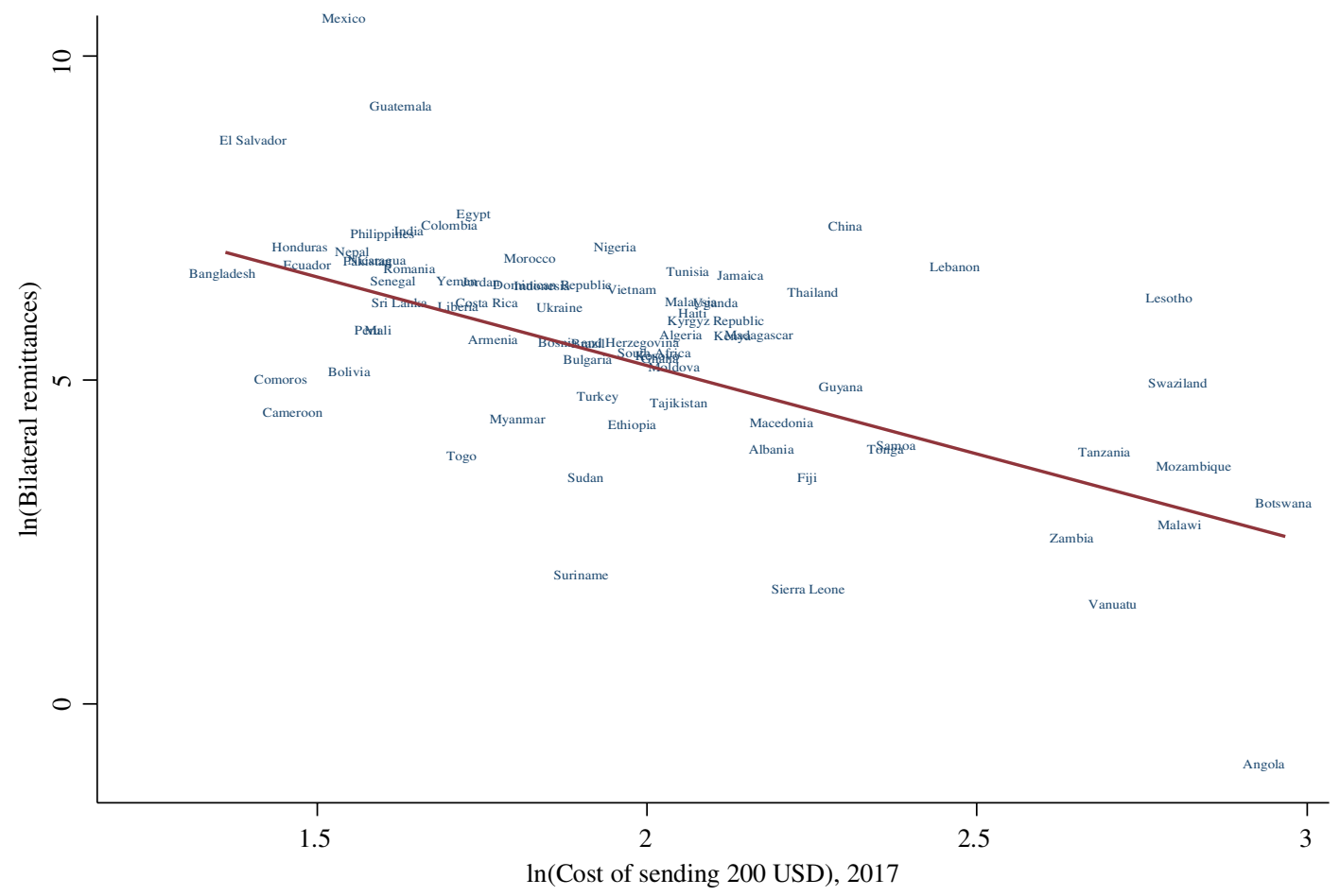

F IG URE A 2 Transaction cost and bilateral remittances, 2017.

SOURCE: REMITTANCE PRICES WORLDWIDE AND REMITTANCES ARE TAKEN FROM THE WORLD BANK. 